\title{
EKSPLORASI BAKTERI FILOSFER DARI TANAMAN MANGROVE SEBAGAI BAKTERI PROBIOTIK PADA BUDI DAYA UDANG WINDU, Penaeus monodon
}

\author{
Muliani, Nurbaya, Arifuddin Tompo, dan Muharijadi Atmomarsono
}

\begin{abstract}
ABSTRAK
Penelitian bertujuan untuk mengeksplorasi bakteri filosfer dari tanaman mangrove sebagai bakteri probiotik pada budi daya udang windu. Penelitian ini terdiri atas beberapa tahapan kerja yaitu: (1) isolasi bakteri filosfer dari tanaman mangrove; (2) uji daya hambat bakteri filosfer terhadap V. harveyi; (3) karakterisasi fisiologi dan biokimia; (4) pertumbuhan bakteri filosfer pada beberapa konsentrasi NaCl; (5) pertumbuhan bakteri filosfer pada beberapa tingkat salinitas; (6) uji patogenisitas bakteri filosfer terhadap pascalarva udang windu; (7) uji tantang bakteri filosfer dengan $V$. harveyi dalam wadah pemeliharaan pascalarva udang windu; (8) identifikasi dan disain pohon filogenetik bakteri filosfer melalui analisis gen 16S-rRNA. Sebanyak 1.145 isolat bakteri filosfer telah diisolasi dari daun mangrove dan dianalisis daya hambatnya terhadap $V$. harveyi baik secara In Vitro maupun In Vivo dan 8 isolat (1\%) di antaranya potensial sebagai bakteri probiotik. Isolat BR53 dan isolat PK446 menghambat pertumbuhan $V$. harveyi secara In Vitro dengan daya hambat masing-masing $6,8 \mathrm{~mm}$ dan $6,97 \mathrm{~mm}$. Ke-8 isolat bakteri filosfer termasuk bakteri gram negatif (kecuali BR883), indol negatif, katalase positif, oksidase positif (kecuali BR931 dan PK446), motil, tidak memproduksi gas dan $\mathrm{H}_{2} \mathrm{~S}$, dan MR-VP negatif, tumbuh pada $\mathrm{NaCl} 10 \%$ dan salinitas $0-50$ ppt. Bakteri filosfer tersebut tidak bersifat patogen terhadap pascalarva udang windu $\left(P L\right.$ 15) pada konsentrasi $10^{4} \mathrm{cfu} / \mathrm{mL}$. Sintasan larva udang windu tertinggi pada perlakuan yang menggunakan isolat BR931 sebagai probiotik. Namun demikian tidak terdapat perbedaan yang nyata $(P>0,05)$ dengan MR53, PK446, dan BR883, tetapi berbeda nyata $(P<0,05)$ dengan kontrol. Berdasarkan hasil analisis sekuen gen 16 S-rRNA, isolat PK446 teridentifikasi sebagai Kluyvera cryocrescens dengan tingkat kemiripan 79,09\%; BR 883 Staphylococcus xylosus dengan tingkat kemiripan 87,22\%; BR 931 termasuk Pseudomonas putida strain $\mathrm{R}$ dengan tingkat kemiripan $87,70 \%$.
\end{abstract}

\section{ABSTRACT: Exploration of phylosfer bacteria from mangrove leaves as potential probiotic bacteria in tiger shrimp, Penaeus monodon culture. By: Muliani, Nurbaya, Arifuddin Tompo, and Muharijadi Atmomarsono}

The research was aimed to find the phylosfer bacteria isolated from mangrove leaves as potential probiotic in tiger shrimp culture. The experiment consisted of several steps i.e. (1) isolation of phylosfer bacteria from mangrove leaves; (2)inhibition test of phylosfer bacteria against $\boldsymbol{V}$. harveyi; (3) biochemical and physiological characterization, (4) growth of phylosfer bacteria in several concentration of $\mathrm{NaCl}$; (5) growth of phylosfer bacteria in different salinity; (6) pathogenecity test of phylosfer bacteria to tiger shrimp post larvae, (7) challenge test of phylosfer bacteria against $\boldsymbol{V}$. harveyi in tiger shrimp culture media (8) identification and phylogenetic tree design of phylosfer bacteria by 16S-rRNA gen analysis. Eleven hundred and fourteen isolates of phylosfer bacteria were isolated from mangrove leaves and analyzed for their inhibitory effects against $\boldsymbol{V}$. harveyi both In Vitro and In Vivo experiments, and 8 isolates (1\%) are potential as probiotic bacteria. MR53 and PK446 isolate demonstrated vibriostatic activity with $6.8 \mathrm{~mm}$ and $6.97 \mathrm{~mm}$ diameter of inhibition zone respectively. Physiological and biochemical characterization of the 8 isolates showed that all of them were gram negative (except BR883), indole negative, MR-VP negative, catalase positive, oxidase positive (excetp BR931 and PK446), motile, and not producing gas and $\mathrm{H}_{2} \mathrm{~S}$. These phylosfer bacteria, grow on $10 \%$ of $\mathrm{NaCl}$ and $0-50$ ppt of water salinity. The phylosfer bacteria, at concentration of $10^{4} \mathrm{cfu} / \mathrm{mL}$, were not pathogenic to tiger shrimp. The highest survival rate of tiger shrimp larvae was at treatment using BR931 isolate as probiotic. Although there were not significantly different between MR53, PK446, and BR883, but there were significantly different to control. Based on 16S-rRNA sequencing, PK446 isolate is closely related (79.09\%) to DNA sequence of Kluyvera cryocrescens 16S-rRNA, BR883 is closely related $(87.22 \%)$ to DNA sequence of Staphylococcus xylosus 16S-rRNA, BR931 is closely related (87.70\%) to DNA sequence of Pseudomonas putida 16S-rRNA.

KEYWORDS: $\quad$ phylosfer, probiotic, mangrove, tiger shrimp

Peneliti pada Balai Riset Perikanan Budidaya Air Payau, Maros 


\section{PENDAHULUAN}

Beberapa tahun terakhir ini budi daya udang windu di Indonesia mengalami keterpurukan akibat serangan penyakit baik di panti perbenihan maupun di tambak pembesaran yang berakibat pada penurunan produksi. Penurunan produksi udang windu di Indonesia terlihat pada periode 1992-1994 yaitu dari 98.356 MT menjadi 83.193 MT atau sebesar 15\% (Anonymous, 1999). Sumber lain menyebutkan bahwa ekspor udang Indonesia ke Jepang mengalami penurunan selama periode 1994-1998 yaitu dari 63.666 MT menjadi 53.411 MT (Ferdouse, 1999).

Serangan penyakit pada budi daya udang windu yang disebabkan oleh bakteri maupun virus tidak hanya terjadi di Indonesia tetapi juga di negara-negara lain seperti Thailand (Jiravanichpaisal et at., 1994; Wongteerasupaya et al., 1995; Chanratchakool \& Limsuwan 1998; Pasharawipas et al., 1998; Ruangpan, 1998; Sukhumsirichart et al., 1998); Taiwan (Kou et al., 1998; Loh et al., 1998; Peng et al., 2001), Filipina (Lavilla-Pitogo et al., 1990 dan 1992; Albaladejo et al., 1998; Loh et al., 1998), India (Karunasagar, 2003; Vaseeharan et al., 2003), Australia ( Spann et al., 1995), Jepang (Itami et al., 1998; Kono et al., 2004), dan Amerika (Dhar et al., 2001)

Berbagai penelitian telah dilakukan untuk mendapatkan suatu metode pencegahan dan penanggulangan penyakit pada udang windu antara lain melalui; (1) penggunaan obat-obatan dan antibiotik (Karunasagar et al., 1994); (2) penggunaan tandon dan biofilter (Atmomarsono et al., 1995; Chanratchakool et al., 1995; Muliani et al., 1998a); (3) penggunaan vaksin dan immunostimulan (Itami \& Takashi, 1991; Sung et al., 1994; dan Devaraja et al., 1998; Vargas-Albores et al., 1998); dan (4) penggunaan bahan aktif dari sponge dan hydrozoan sebagai antibakteri (Ahmad et al., 1995; Muliani et al., 1996; dan 1998b; dan Suryati et al., 2000).

Penggunaan bakteri yang diisolasi dari berbagai sumber sebagai probiotik juga telah banyak dilaporkan (Tjahyadi et al., 1994; Rosa et al., 1997; Hala, 1999; Hala \& Suwanto, 2003; Haryanti et al., 2000; Muliani et al., 2003). Menurut Wang et al. (1999), fungsi paling penting dalam penggunaan probiotik adalah mempertahankan kestabilan parameter kualitas air tambak dengan menurunkan bahan organik seperti amonia, gas hidrogen sulfida, dan gas-gas beracun lainnya. Selain itu probiotik juga mengontrol terjadinya blooming alga, sehingga dapat menjaga kestabilan nilai $\mathrm{pH}$ dalam tambak, menurunkan kadar $\mathrm{BOD}$, dan menjaga ketersediaan oksigen bagi pertumbuhan udang.
Meskipun beberapa bakteri probiotik telah mulai dikembangkan, namun pemanfaatannya belum maksimal karena adanya beberapa kendala seperti optimalisasi pertumbuhan, konsistensi daya hambat atau daya urainya, dan kemampuan beradaptasi. Mengingat bahwa tanaman mangrove merupakan vegetasi alami daerah pertambakan, maka diperlukan eksplorasi bakteri filosfer dari daun mangrove yang dapat dijadikan sebagai sumber bakteri probiotik pada budi daya udang windu. Bakteri filosfer secara umum merupakan bakteri penghuni permukaan daun pada tumbuh-tumbuhan baik yang hidup di dataran tinggi maupun di dataran rendah. Dengan mengisolasi bakteri penghuni permukaan daun mangrove diharapkan ditemukan kandidat probiotik yang dapat digunakan untuk penanggulangan penyakit budi daya udang windu.

\section{BAHAN DAN METODE}

\section{Isolasi Bakteri Filosfer}

Bakteri filosfer diisolasi dari daun mangrove dan asosiasinya yang dikoleksi dari beberapa lokasi di Sulawesi Selatan. Daun mangrove yang masih segar dimasukkan ke dalam wadah yang telah disterilkan dan selanjutnya dibawa ke laboratorium patologi Balai Riset Perikanan Budidaya Air Payau (BRPBAP), Maros. Isolasi bakteri filosfer dilakukan dengan dua teknik yaitu; (1) teknik replika dan (2) dengan perendaman dalam larutan bufferatau larutan fisiologis ( $\mathrm{NaCl}$ 0,85\%). Pada teknik replika daun digunakan media agar King B agar (20 g Pepton; 15 mL Glyserol; $1,5 \mathrm{~g} \mathrm{~K}_{2} \mathrm{HPO}_{4} ; 1,5 \mathrm{~g} \mathrm{MgSO}_{4} .7 \mathrm{H}_{2} \mathrm{O} ; 20 \mathrm{~g}$ agar; akuades 1 liter) dalam cawan petri atau SWC. Daun mangrove diambil kemudian diletakkan pelan di atas permukaan agar. Dibiarkan sebentar sampai terbentuk replika daun pada media tersebut. Hal yang sama dilakukan untuk permukaan daun yang berlawanan. Selanjutnya diinkubasi pada suhu ruang selama 1-2 hari. Koloni yang tumbuh dipisahkan dengan menggunakan media King B yang dimiringkan. Sedangkan pada teknik perendaman digunakan buffer fosfat atau larutan garam fisiologis. Daun mangrove dimasukkan ke dalam tabung reaksi yang telah berisi buffer atau larutan fisiologis, kemudian divortex selama 30 detik supaya bakterinya terlepas dan tersuspensi. Selanjutnya dibuat pengenceran secara berseri (bisa sampai $10^{-2}$ ). Setiap pengenceran diambil $100 \mathrm{~mL}$ dan disebar pada media agar King B dalam cawan petri. Selanjutnya diinkubasi pada suhu ruang selama 12 hari. Koloni bakteri yang tumbuh pada media diidentifikasi berdasarkan bentuk, warna, elevasi, dan ukuran koloni (Austin, 1993; Austin \& Austin, 1993; Hadioetomo, 1993; Atlas, 1997; Prescott et al., 2002). Kemudian dimurnikan dengan media agar King $B$ yang 
dimiringkan dan selanjutnya diuji daya hambatnya terhadap bakteri $V$. harveyi.

\section{Uji Daya Hambat Bakteri Filosfer terhadap $V$. harveyi}

\section{Secara kualitatif}

Semua bakteri yang telah diisolasi dari daun mangrove diuji daya hambatnya terhadap $V$. harveyi yang disolasi dari udang windu, $V$. harveyi ditumbuhkan pada TCBSA selama 24 jam. Koloni tunggal yang tumbuh diambil dengan jarum Ose dan disuspensikan dalam larutan garam fisiologis. Kemudian disebar pada media Muller Hinton dalam cawan petri dan didiamkan selama beberapa menit hingga kering, selanjutnya di atas permukaan agar tersebut diinokulasi dengan bakteri filosfer secara goresan. Biakan bakteri tersebut diinkubasi pada suhu ruang selama 24 jam. Isolat yang menghambat pertumbuhan $V$. harveyiyang ditandai dengan adanya zona bening di sekitarnya, disimpan untuk selanjutnya diuji lanjut untuk menentukan daya hambat isolat tersebut secara semi kuantitatif menggunakan paper disk.

\section{Secara semi kuantitatif}

Di atas permukaan media Muller Hinton Agar Plate yang telah disebari dengan $V$. harveyi ditaruh paper disk steril yang berdiameter $6 \mathrm{~mm}$. Koloni tunggal dari bakteri kandidat biokontrol (biakan 24 jam) disuspensikan dalam larutan garam fisiologis $50 \mathrm{~mL}$ dalam tabung Eppendorf, kemudian sebanyak 10$20 \mathrm{~mL}$ diteteskan pada paper disk tersebut. Selanjutnya diinkubasi pada suhu $28^{\circ} \mathrm{C}$ selama 24 jam. Setelah itu diukur zona bening yang terbentuk menggunakan mikrometer pada 3 posisi dari setiap paper disk, kemudian dirata-ratakan.

\section{Karakterisasi bakteri kandidat biokontrol sifat fisiologi dan biokimia}

Semua bakteri filosfer yang menghambat $V$. harveyi dikarakterisasi secara fisiologi dan biokimia yang meliputi; pewarnaan gram, oksidase, katalase, indol, motilitas, MR-VP, produksi H2S, dan King A dan B (Austin, 1993; Austin \& Austin, 1993; Hadioetomo 1993; Alsina \& Blanch, 1994; Muir, 1996).

\section{Resistensi terhadap beberapa antibiotik dan pembuatan mutan spontan}

Media yang dipakai untuk mempelajari resistensi antibiotik adalah Muller Hinton Agar $(\mathrm{MH})$ yang dimodifikasi dengan penambahan antibiotik gentamisin, kloramfenikol, eritromisin, furazolidon, dan rifampisin dengan konsentrasi masing-masing $25 \mathrm{mg} /$ $\mathrm{mL}$. Isolat bakteri filosfer potensial sebagai probiotik digoreskan pada masing-masing media tersebut, lalu diinkubasi pada suhu ruang selama 20--24 jam. Respon resistensi dari isolat dapat diketahui dengan mengamati pertumbuhan koloni di atas media tersebut (Hala, 1999).Pembuatan mutan resisten rifampisin $\left(\right.$ Rif $\left.^{\circledR}\right)$ dilakukan terhadap semua isolat bakteri filosfer yang potensial sebagai probiotik dengan menggunakan media Nutrien Broth (NB) yang disuplementasi dengan rifampisin $50 \mathrm{mg} / \mathrm{mL}$. Kultur sel yang berumur 24 jam sebanyak $500 \mathrm{~mL}$. disentrifus dengan kecepatan 300 rpm. Pelet yang terbentuk diresuspensi kembali dalam $100 \mathrm{~mL}$ garam fisiologis dan selanjutnya disebar pada media $\mathrm{MH}$ dalam cawan petri, lalu diinkubasi pada suhu ruang $\left(28^{\circ} \mathrm{C}-32^{\circ} \mathrm{C}\right)$ selama $24 \mathrm{jam}$. Koloni yang tumbuh pada media $\mathrm{MH}$ dalam cawan petri, digoreskan kembali pada media yang sama untuk digunakan dalam uji selanjutnya.

\section{Uji pertumbuhan bakteri filosfer pada beberapa konsentrasi $\mathrm{NaCl}$}

Pada tahapan ini dilakukan secara In Vitro pada media Nutrient Broth dalam cawan labu erlenmeyer. $\mathrm{Ke}$ dalam media tersebut ditambahkan $\mathrm{NaCl}$ dengan konsentrasi $0 \% ; 0,01 \% ; 0,1 \% ; 1 \%$; dan $10 \%$. Satu ose biakan bakteri filosfer dimasukkan ke dalam erlenmeyer yang berisi media Nutrient Broth, kemudian diinkubasi selama 24-48 jam. Selanjutnya ditumbuhkan kembali pada media King $B$ dalam cawan petri untuk melihat pertumbuhan bakteri filosfer.

\section{Uji pertumbuhan bakteri filosfer pada salinitas yang berbeda}

Wadah yang digunakan untuk uji pertumbuhan adalah akuarium kaca berkapasitas $3 \mathrm{~L}$ yang telah disterilkan dengan kaporit $150 \mathrm{mg} / \mathrm{L}$ dan dinetralisir dengan Natrium Thiosulfat $75 \mathrm{mg} / \mathrm{L}$. Salinitas air yang dicobakan adalah 0 ppt, 10 ppt, 20 ppt, 30 ppt, 40 $\mathrm{ppt}$, dan $50 \mathrm{ppt}$ (untuk melihat kemungkinan aplikasi bakteri tersebut baik pada salinitas rendah di musim hujan maupun salinitas tinggi di musim kemarau). Setiap perlakuan diulang 3 kali. Pengamatan populasi bakteri dilakukan sesuai dengan pola pertumbuhan bakteri tersebut yang telah diketahui melalui uji pendahuluan secara In Vitro.

\section{Uji patogenisitas bakteri filosfer terhadap pascalarva udang windu}

Semua peralatan dan air laut yang digunakan untuk uji patogenisitas didisinfeksi dengan merendam dalam larutan kaporit $150 \mathrm{mg} / \mathrm{L}$ kurang lebih 3 hari, kemudian dinetralisir dengan penambahan Natrium Thiosulfat 
dengan konsentrasi $75 \mathrm{mg} / \mathrm{L}$. Selanjuinya dicuci dengan air yang juga telah disterilkan dengan kaporit dan dinetralisir dengan Natrium Thiosulfat dengan konsentrasi yang sama yaitu $150 \mathrm{mg} / \mathrm{L}$ dan $75 \mathrm{mg} / \mathrm{L}$.

Hewan uji yang digunakan berupa pascalarva udang windu PL15. Sebelum digunakan larva udang terlebih dahulu diadaptasikan selama 3-4 hari untuk menyesuaikan salinitas media pemeliharaan dengan salinitas asal larva udang.

Bakteri filosfer yang potensial sebagai probiotik selanjutnya diuji patogenisitasnya terhadap pascalarva udang windu. Satu ose dari masing-masing isolat ditumbuhkan dalam media NB secara terpisah. Kultur ditempatkan pada inkubator bergoyang selama $24 \mathrm{jam}$ pada suhu ruang. Selanjutnya diuji patogenisitasnya terhadap larva udang windu pada konsentrasi $10^{4} \mathrm{cfu} /$ $\mathrm{mL}$ (Hala, 1999) secara perendaman (Hameed, 1995). Wadah yang digunakan untuk uji patogenisitas adalah akuarium kaca berkapasitas $3 \mathrm{~L}$ yang telah disterilkan dengan kaporit $150 \mathrm{mg} / \mathrm{L}$ dan dinetralisir dengan Natrium Thiosulfat $75 \mathrm{mg} / \mathrm{L}$. Setiap wadah diisi air laut steril dengan salinitas 20 ppt sebanyak $2 \mathrm{~L}$ dan ditebari dengan pascalarva udang sebanyak 30 ekor/ wadah. Untuk menjaga ketersediaan oksigen, wadah pemeliharaan udang dilengkapi dengan aerasi dan untuk mempertahankan suhu, wadah ditempatkan pada ruang yang terkontrol dan ditutup dengan plastik hitam. Pemberian pakan dilakukan sebanyak dua kali per hari sebanyak $10 \%$ dari bobot tubuh. Patogenisitas bakteri filosfer diamati melalui kematian pascalarva udang setelah 48 jam perendaman dan dibandingkan dengan kontrol (tanpa infeksi bakteri filosfer).

\section{Uji Tantang Bakteri V. harveyi dengan Bakteri Filosfer}

Uji tantang $V$. harveyi dengan bakteri filosfer secara In Vivo dilakukan di Laboratorium Basah Balai Riset Perikanan Budidaya Air Payau (BRPBAP), Maros. Penelitian dilakukan menggunakan rancangan acak lengkap dengan tiga kali ulangan. Kepadatan bakteri $V$. harveyi dibuat menjadi $10^{7} \mathrm{cfu} / \mathrm{mL}$, dan bakteri filosfer dibuat menjadi $10^{4} \mathrm{cfu} / \mathrm{mL}$. Wadah yang digunakan untuk uji tantang secara in Vivo adalah stoples kaca berkapasitas $3 L$ yang telah didesinfeksi dengan kaporit $150 \mathrm{mg} / \mathrm{L}$ dan dinetralisir dengan Natrium Thiosulfat $75 \mathrm{mg} / \mathrm{L}$. Setiap wadah diisi air laut steril dengan salinitas 20 ppt sebanyak $2 \mathrm{~L}$. Suspensi bakteri filosfer dimasukkan ke dalam wadah pemeliharaan pascalarva udang windu dua jam sebelum udang dimasukkan. Setelah kokultivasi dengan larva udang sebanyak 30 ekor/wadah selama 6 jam, $V$. harveyi sebagai patogen selanjutnya dimasukkan ke dalam wadah perneliharaan (Hala, 1999). Pengamatan sintasan pascalarva udang windu dilakukan 96 jam perendaman. Untuk mengetahui perbedaan sintasan pascalarva udang windu, maka data dianalisis ragam dan dilanjutkan dengan uji beda nyata terkecil (Steel \& Torrie, 1981).

\section{Identifikasi dan Disain Pohon Filogenetik Bakteri Filosfer melalui Analisis Gen 16S- rRNA}

Untuk menentukan identitas isolat bakteri filosfer yang menghambat pertumbuhan $V$. harveyi dan potensial sebagai bakteri probiotik berdasarkan sekuen 16S-rRNA, maka dilakukan analisis yang meliputi beberapa tahapan sesuai dengan metode yang dikemukakan oleh Marchesi et al. (1998) dan telah dimodifikasi oleh Suwanto et al. (2000) yaitu meliputi ekstraksi DNA, amplifikasi gen 16S-rRNA dengan PCR, gene clean dengan metode glass milk, Cycle sequensing dengan metode BigDye, presipitasi DNA, dan sekuensing dengan mesin Sequenser.

\section{HASIL DAN BAHASAN}

Telah diperoleh sedikitnya 1.145 isolat bakteri filosfer yang diisolasi dari daun mangrove. Berdasarkan hasil penapisan terhadap ke-1.145 isolat tersebut, 8 isolat $(1 \%)$ dari total isolate, merupakan isolate potensial sebagai bakteri probiotik dan 2 isolat di antaranya menghambat $V$. harveyi secara In vitro. Sejauh ini belum ada laporan tentang potensi bakteri filosfer dari daun mangrove sebagai bakteri probiotik, namun demikian fungsi mangrove sebagai bioremediasi dan biofilter pada budi daya udang windu telah dilaporkan (Ahmad et al., 2001). Lain halnya dengan bakteri laut, beberapa peneliti telah melaporkan potensinya sebagai sumber bakteri probiotik pada komoditas perikanan. Tjahjadi et al. (1994) melaporkan bahwa dari 45 isolat bakteri dari air laut dan air pemeliharaan larva udang windu, $8 \mathrm{di}$ antaranya diuji daya hambatnya secara in vitro terhadap pertumbuhan $V$. harveyi dan 3 atau $6,7 \%$ di antaranya potensial menghambat pertumbuhan $V$. harveyi. Rosa et al. (1997) juga telah mengisolasi 125 isolat bakteri dari air laut, air tambak, air pemeliharaan larva, serta tubuh udang dan 15 atau $12 \%$ di antaranya mempunyai daya hambat terhadap perkembangan $\mathrm{V}$. harveyi. Sedangkan Haryanti et al. (2000) telah mengisolasi sedikitnya 273 isolat bakteri laut dan 3 atau $1 \%$ di antaranya memperlihatkan hambatan terhadap pertumbuhan $V$. harveyi secara In Vitro. Muliani et al. (2003) telah mengisolasi sedikitnya 603 isolat bakteri laut dan 2,5\% di antaranya menghambat pertumbuhan $V$. harveyi secara In Vitro dan In Vivo.

Karakteristik morfologi kedelapan isolat bakteri filosfer yang diisolasi dari daun mangrove dan potensial sebagai bakteri probiotik disajikan pada Tabel 1 . 
Tabel 1. Karakteristik secara morfologi bakteri filosfer dari daun mangrove yang potensial sebagai probiotik pada budi daya udang windu

Table 1. Morfological characterization of phylosfer bacteria as potencial probiotic in tiger shrimp culture

\begin{tabular}{|c|c|c|c|c|c|}
\hline \multirow{2}{*}{$\begin{array}{l}\text { Kode isolat } \\
\text { (Isolate Code) }\end{array}$} & \multirow{2}{*}{$\begin{array}{c}\text { Asal } \\
\text { (Source) }\end{array}$} & \multicolumn{4}{|c|}{ Ciri-ciri koloni (Colony characteristics) } \\
\hline & & $\begin{array}{l}\text { Bentuk/Ukuran } \\
\text { (Shape/Size) }\end{array}$ & $\begin{array}{l}\text { Tepian } \\
\text { (Margin) }\end{array}$ & $\begin{array}{l}\text { Elevasi } \\
\text { (Elevation) }\end{array}$ & $\begin{array}{l}\text { Warna } \\
\text { (Color) }\end{array}$ \\
\hline MR53 & Maros & $\begin{array}{l}\text { Tak beraturan } \\
\text { Irregular }\end{array}$ & $\begin{array}{l}\text { Bergerigi } \\
\text { Erose }\end{array}$ & $\begin{array}{l}\text { Cembung } \\
\text { Pulvinate }\end{array}$ & Putih (white) \\
\hline BR931 & Barru & $\begin{array}{l}\text { Bundar/Kecil } \\
\text { Circular/Small }\end{array}$ & $\begin{array}{l}\text { Licin } \\
\text { Entire }\end{array}$ & $\begin{array}{l}\text { Cembung } \\
\text { Pulvinate }\end{array}$ & Orange (Orange) \\
\hline PK446 & Pangkep & $\begin{array}{l}\text { Bundar/Sedang } \\
\text { Circular/Medium }\end{array}$ & $\begin{array}{l}\text { Licin } \\
\text { Entire }\end{array}$ & $\begin{array}{l}\text { Cembung } \\
\text { Pulvinate }\end{array}$ & Kuning (Yellow) \\
\hline BL583 & Bulukumba & $\begin{array}{l}\text { Bundar/Besar } \\
\text { Circular/Big }\end{array}$ & $\begin{array}{l}\text { Licin } \\
\text { Entire }\end{array}$ & $\begin{array}{l}\text { Timbul } \\
\text { Convex }\end{array}$ & $\begin{array}{l}\text { Putih kekuningan } \\
\text { Yellow white }\end{array}$ \\
\hline BR878 & Barru & $\begin{array}{l}\text { Tak beraturan } \\
\text { Irregular }\end{array}$ & $\begin{array}{l}\text { Licin } \\
\text { Entire }\end{array}$ & $\begin{array}{l}\text { Datar } \\
\text { Flat }\end{array}$ & $\begin{array}{l}\text { Putih kekuningan } \\
\text { Yellow white }\end{array}$ \\
\hline BR882 & Barru & $\begin{array}{l}\text { Tak beraturan } \\
\text { Irregular }\end{array}$ & $\begin{array}{l}\text { Licin } \\
\text { Entire }\end{array}$ & $\begin{array}{l}\text { Datar } \\
\text { Flat }\end{array}$ & $\begin{array}{l}\text { Hijau berpendar } \\
\text { Green fluorescence }\end{array}$ \\
\hline BR883 & Barru & $\begin{array}{l}\text { Tak beraturan } \\
\text { Irregular }\end{array}$ & $\begin{array}{l}\text { Licin } \\
\text { Entire }\end{array}$ & $\begin{array}{l}\text { Datar } \\
\text { Flat }\end{array}$ & $\begin{array}{l}\text { Hijau berpendar } \\
\text { Green fluorescence }\end{array}$ \\
\hline BR919 & Barru & $\begin{array}{l}\text { Tak beraturan } \\
\text { Irregular }\end{array}$ & $\begin{array}{l}\text { Licin } \\
\text { Entire }\end{array}$ & $\begin{array}{l}\text { Cembung } \\
\text { Pulvinate }\end{array}$ & $\begin{array}{l}\text { Putih kekuningan } \\
\text { Yellow white }\end{array}$ \\
\hline
\end{tabular}

\section{Hasil Uji Daya Hambat Bakteri Filosfer} terhadap Vibrio harveyi

Hasil uji daya hambat bakteri filosfer terhadap $V$. harveyi menunjukkan bahwa ada dua isolat yang memiliki daya hambat yang cukup potensial terhadap V. harveyi yaitu isolat MR53 (6,8 mm), dan PK446 $(6,97 \mathrm{~mm})$. Daya hambat kedua jenis bakteri terhadap $V$. harveyilebih rendah dibanding dengan daya hambat bakteri laut yang telah dilaporkan sebelumnya yaitu isolat BL542 dengan zona hambatan terbesar (11,5 $\mathrm{mm})$, dan isolat BL546 dan BL547 yang masingmasing sebesar $11,1 \mathrm{~mm}$ (Muliani et al., 2003).

\section{Karakterisasi Bakteri Filosfer}

\section{Sifat fisiologi dan biokimia}

Hasil uji fisiologi dan biokimia menunjukkan bahwa semua bakteri filosfer termasuk bakteri gram negatif, kecuali isolat BR883 bersifat gram positif, katalase positif, motil, dan indol negatif dan pada umumnya oksidase positif (kecuali BL 931 dan PK446), tidak menghasilkan gas dan $\mathrm{H}_{2} \mathrm{~S}$, Uji MR-PV negatif, King $A$, dan King $B$ positif.

\section{Resistensi terhadap antibiotik}

Hasil uji resistensi terhadap beberapa macam antibiotik dari ke 8 isolat bakteri filosfer disajikan pada Tabel 2.
Pada Tabel 2, terlihat bahwa semua isolat bakteri filosfer sensitif terhadap rifamfisin (kecuali BR931), resisten terhadap gentamicin, resisten terhadap furazolidon (kecuali MR53 dan BL 583), resisten terhadap kloramfenicol (kecuali BL583 dan BR919) dan resisten terhadap eritromisin (kecuali isolat BL583). Hal ini menunjukkan bahwa secara alami bakteri dapat bersifat resisten terhadap suatu antibiotik.

Sifat resistensi tersebut diperlukan oleh suatu mikroorganisme untuk mempertahankan sintasannya di alam. Menurut Chythanya et al. (1999), secara alami beberapa jenis mikroorganisme memiliki gen penyandi antibiotik yang dapat melindungi dirinya dari serangan antibiotik dari luar. Sifat resistensi terhadap suatu jenis antibiotik dari suatu bakteri perlu diketahui sebelum ditetapkan jenis antibiotik yang akan digunakan sebagai penanda terhadap bakteri tersebut. Hal ini akan memudahkan untuk menyeleksi bakteri tersebut dari bakteri yang secara alami sensitif terhadap antibiotik yang digunakan.

\section{Uji Pertumbuhan Bakteri Filosfer terhadap Beberapa Konsentrasi $\mathrm{NaCl}$}

Pertumbuhan ke-8 isolat pada kadar $\mathrm{NaCl}$ yang berbeda disajikan pada Tabel 3. Dari tabel tersebut terlihat bahwa pada umumnya bakteri filosfer masih mampu tumbuh pada konsentrasi $\mathrm{NaCl} 10 \%$. Hal ini 
Tabel 2. Pertumbuhan bakteri filosfer pada media Muller Hinton yang dibubuhi beberapa jenis antibiotik 25 $\mathrm{mg} / \mathrm{mL}$

Table 2. Growth of phylosfer bacteria on Muller Hinton Agar supplemented with $25 \mathrm{mg} / \mathrm{mL}$ of antibiotics

\begin{tabular}{cccccc}
\hline \multirow{2}{*}{$\begin{array}{c}\text { Kode isolat } \\
\text { Isolate code }\end{array}$} & \multicolumn{5}{c}{ Antibiotik (Antibiotics) } \\
\cline { 2 - 6 } & Rf & Gm & Fz & Ch & Em \\
\hline MR53 & - & + & - & + & + \\
BR931 & + & + & + & + & + \\
PK446 & - & + & + & + & + \\
BL583 & - & + & - & - & - \\
BR878 & - & + & + & + & + \\
BR882 & - & + & + & + & + \\
BR883 & - & + & + & + & + \\
BR919 & - & + & + & - & + \\
\hline
\end{tabular}

Keterangan: Rf $=$ Rifampisin, $\mathrm{Gm}=$ Gentamisin, $\mathrm{Fz}=$ Furazolidon, $\mathrm{Ch}=$ Chlorampenicol, Em $=$ Eritromisin, $(\cdot)=$ sensitif, $(+)$ = resisten

Note: $\quad R f=$ Rifampisin, $G m=$ Gentamisin, $F z=$ Furazolidon, $C h=$ Chlorampenicol, Em $=$ Eritromisin, $\left({ }^{\circ}\right)=$ sensitive, $(+)=$ resistant

Tabel 3. Pertumbuhan bakteri filosfer pada beberapa konsentrasi $\mathrm{NaCl}$

Table 3. Growth of phylosfer bacteri on several concentrations of $\mathrm{NaCl}$

\begin{tabular}{cccccc}
\hline \multirow{2}{*}{$\begin{array}{c}\text { Kode isolat } \\
\text { Isolate code }\end{array}$} & \multicolumn{5}{c}{$\begin{array}{c}\text { Konsentrasi NaCl (\%) } \\
\text { NaCl concentration (\%) }\end{array}$} \\
\cline { 2 - 6 } & 0 & 0.01 & 0.1 & 1 & 10 \\
\hline MR53 & + & + & + & + & + \\
PK446 & + & + & + & + & + \\
BL583 & + & + & + & + & + \\
BR882 & + & + & + & + & + \\
BR883 & + & + & + & + & + \\
BR878 & + & + & + & + & + \\
BR919 & + & + & + & + & + \\
BR931 & + & + & + & + & + \\
\hline
\end{tabular}

menunjukkan kemungkinan penggunaannya sebagai bakteri probiotik pada budi daya air payau.

\section{Uji Pertumbuhan Bakteri Filosfer pada Salinitas yang Berbeda}

Dari delapan isolat bakteri filosfer yang telah diuji pertumbuhannya terhadap beberapa konsentrasi $\mathrm{NaCl}$, 4 isolat di antaranya diuji lanjut untuk mengetahui toleransinya terhadap beberapa tingkatan salinitas (Tabel 4). Hasil penelitian menunjukkan bahwa keempat isolat tersebut tumbuh pada semua tingkatan salinitas yang diujikan (0-50 ppt), meskipun ada kecenderungan beberapa isolat tumbuh optimal pada kisaran salinitas 20-40 ppt. Hal ini menunjukkan bahwa bakteri filosfer yang diisolasi dari daun mangrove bersifat toleran terhadap kisaran salinitas yang lebar. Dengan demikian bakteri filosfer yang diisolasi dari daun mangrove memiliki peluang yang sangat besar untuk dikembangkan sebagai probiotik baik pada budi daya air tawar, air payau, maupun laut.

\section{Uji Patogenisitas Bakteri Filosfer terhadap Larva Udang Windu}

Hasil uji patogenisitas 4 isolat bakteri filosfer terhadap pascalarva udang windu pada konsentrasi $\left(10^{4} \mathrm{cfu} / \mathrm{mL}\right)$ disajikan pada Tabel 5.

Dari Tabel 5 terlihat bahwa sintasan pascalarva udang windu tertinggi pada perlakuan yang menggunakan BR931 dan BR883, kemudian berturutturut MR53, PK446, dan kontrol. Dari data tersebut terlihat bahwa pada umumnya bakteri filosfer tidak bersifat patogen terhadap larva udang windu, karena 
Tabel 4. Rata-rata pertumbuhan bakteri filosfer pada salinitas yang berbeda setelah 24 jam Table 4. Growth rate of phylosfer bacteria on different salinities after 24 hours

\begin{tabular}{ccccccc}
\hline \multirow{2}{*}{$\begin{array}{c}\text { Kode isolat } \\
\text { Isolate code }\end{array}$} & \multicolumn{7}{c}{$\begin{array}{c}\text { Salinitas (ppt) } \\
\text { Salinity (ppt) }\end{array}$} \\
\cline { 2 - 7 } & 0 & 10 & 20 & 30 & 40 & 50 \\
\hline MR53 & $2.9 \times 103$ & $3.1 \times 104$ & $3.3 \times 103$ & $1.9 \times 103$ & $8.8 \times 102$ & $1.2 \times 102$ \\
PK446 & $4.0 \times 103$ & $4.3 \times 102$ & $5.3 \times 103$ & $2.3 \times 103$ & $9.7 \times 102$ & $8.4 \times 102$ \\
BR882 & $5.9 \times 104$ & $7.7 \times 103$ & $9.4 \times 104$ & $6.8 \times 104$ & $1.7 \times 105$ & $7.3 \times 104$ \\
BR931 & $2.3 \times 105$ & $5.2 \times 103$ & $9.3 \times 105$ & $4.1 \times 105$ & $1.2 \times 105$ & $6.2 \times 105$ \\
\hline
\end{tabular}

sintasan pascalarva udang windu masih lebih tinggi dibanding dengan kontrol. Namun sintasan ini secara statistik tidak menunjukkan perbedaan yang nyata $(P>0,05)$. Hal ini menunjukkan bahwa bakteri filosfer yang diisolasi dari daun mangarove dapat dijadikan probiotik pada budi daya udang windu dengan mengaplikasikan langsung sel utuh dari bakteri tersebut.

\section{Sintasan Pascalarva Udang Windu yang Diuji Tantang dengan $V$. harveyi}

Hasil pengamatan terhadap sintasan pascalarva udang windu PL 15 pada uji tantang secara In Vivo antara bakteri filosfer dengan $V$. harveyidapat dilihat pada Tabel 6.

Dari tabel tersebut terlihat bahwa sintasan pascalarva udang windu tertinggi pada perlakuan yang menggunakan isolat BR931 sebagai probiotik, kemudian berturut-turut. MR53, PK446, BR883, dan terendah pada kontrol (tanpa pemberian bakteri filosfer). Hasil uji statistik menunjukkan bahwa terdapat perbedaan yang nyata $(P<0,05)$ antara sintasan udang pada perlakuan yang menggunakan isolat BR931 dengan kontrol, namun tidak ada perbedaan yang nyata $(P>0,05)$ antara sintasan udang yang menggunakan isolat BR931 dengan isolat isolat MR53, PK446, dan BR883, demikian pula antara isolat MR53, PK446, dan BR883 dengan kontrol tidak berbeda nyata $(P>0,05)$. Tingginya sintasan larva udang windu pada perlakuan yang menggunakan isolat BR931 dibanding perlakuan lainnya diduga karena isolat ini tergolong dalam kelompok bakteri Pseudomonas putida Strain R (berdasarkan hasil sekuen 16S-rRNA) dengan tingkat kemiripan $87,70 \%$ (data EMBL/GenBank/DDBJ database). Kelompok bakteri ini banyak digunakan sebagai bakteri probiotik dan telah dijual bebas di pasaran. Kelompok bakteri ini selain sebagai bakteri pengurai juga beberapa di antaranya bersifat antagonisme terhadap bakteri lain . Sebagaimana yang telah dilaporkan oleh Gram et al. (1999), bahwa Pseudomonas fluorescens dapat menghambat pertumbuhan bakteri Vibrio anguillarum baik secara In Vitro maupun In Vivo.

\section{Disain Pohon Filogenetik}

Selain isolat BR931 dua isolat lainnya (PK446 dan BR883) juga diidentifikasi berdasarkan sekuen 16SrRNAnya. Berdasarkan hasil analisis sekuen gen 16SrRNA dari kedua isolat tersebut menunjukkan bahwa isolat PK446 teridentifikasi sebagai Kluyvera

Tabel 5. Sintasan pascalarva udang windu (\%) setelah 48 jam direndam dalam larutan bakteri filosfer yang berbeda

Table 5. Survival rate of tiger shrimp post larvae (\%) 48 hours after exposed to different phylosfer bacteria

\begin{tabular}{lc}
$\begin{array}{r}\text { Kode isolat } \\
\text { Isolate code }\end{array}$ & $\begin{array}{c}\text { Sintasan pascalarva udang windu (\%) } \\
\text { Survival rate of tiger shrimp larvae (\%) }\end{array}$ \\
\hline MR53 & $85.55^{\mathrm{a}}$ \\
PK446 & $84.45^{\mathrm{a}}$ \\
BR883 & $86.67^{\mathrm{a}}$ \\
BR931 & $86.67^{\mathrm{a}}$ \\
Kontrol (Control) & $82.22^{\mathrm{a}}$ \\
\hline
\end{tabular}

Keterangan (Note): Angka yang diikuti huruf yang berbeda pada kolom yang sama menunjukkan perbedaan yang sangat nyata (Number followed by different alphabet on the same column show the significant differences) 
Tabel 6. Pengaruh bakteri filosfer terhadap sintasan pascalarva udang windu yang diuji tantang dengan $V$. harveyi selama 96 jam pada salinitas 20 ppt

Tabel 6. Effect of phylosfer bacteria on survival rate of tiger shrimp post larvae 96 hours after challenged with $V$. harveyi at water salinity of 20 ppt

\begin{tabular}{lc}
\hline $\begin{array}{c}\text { Kode Isolat } \\
\text { Code isolates }\end{array}$ & $\begin{array}{c}\text { Sintasan pascalarva udang windu (\%) } \\
\text { Survival rate of tiger shrimp post larvae (\%) }\end{array}$ \\
\hline MR53 & $87.77^{\mathrm{ab}}$ \\
PK446 & $82.22^{\mathrm{ab}}$ \\
BR883 & $82.22^{\mathrm{ab}}$ \\
BR931 & $94.44^{\mathrm{a}}$ \\
Kontrol (Control) & $73.33^{\mathrm{b}}$ \\
\hline
\end{tabular}

Keterangan (Note): Angka yang diikuti huruf yang berbeda pada kolom yang sama menunjukkan perbedaan yang sangat nyata (Number followed by different alphabet on the same column show the significant differences)

cryocrescens dengan tingkat kemiripan $79,11 \%$; BR 883 Staphylococcus xylosus dengan tingkat kemiripan $87,22 \%$ (berdasarkan data EMBL/GenBank/DDBJ database).

Staphylococcus sp. termasuk kelompok bakteri gram positif yang bersifat tidak motil dan tidak berspora, ukurannya berkisar 0,9-1,3 $\mathrm{mm}$, berbentuk coccus berantai menyerupai spiral facultative anaerobik, juga biasa digunakan sebagai bakteri probiotik pengurai bahan organik, sedangkan Kluyvera $\mathrm{sp}$. termasuk bakteri gram negatif, MR positif, VP negatif, indol dan citrate positif, membentuk 2- oxoglutarat dari glukosa (Singleton \& Sainsbury, 1999). Pemanfaatan bakteri ini sebagai bakteri probiotik sampai saat ini belum dilaporkan, bakteri ini termasuk bakteri penghuni daun dan sering diidentifikasi sebagai penyebab penyakit pada sayursayuran seperti sawi dan kubis.

Hasil analisis gen 16S-rRNA dari isolat-isolat tersebut selanjutnya dibuat pohon filogenetik untuk mengetahui kedekatan kekerabatan bakteri lain dengan membandingkan 672 basa-basa DNA. Pohon filogenetik tersebut dapat dilihat pada Gambar 1a-$1 \mathrm{c}$.

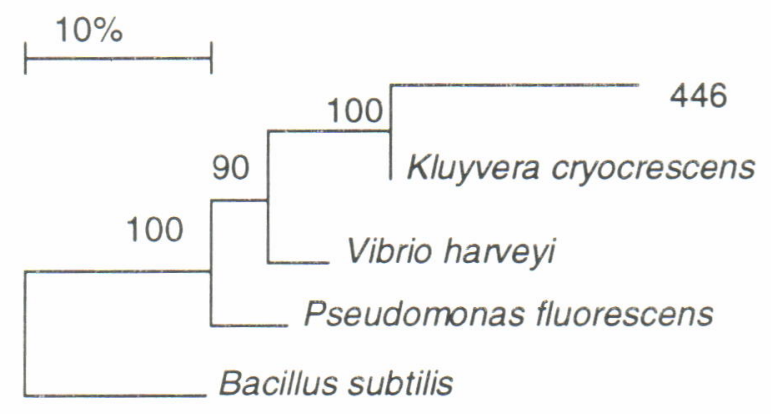

Gambar 1a. Pohon filogenetik isolat PK446

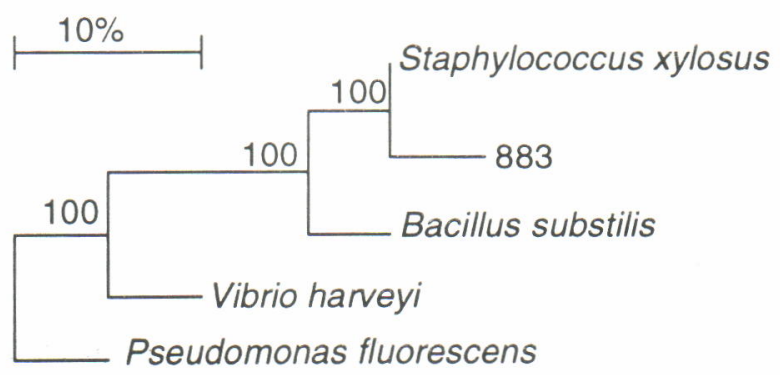

Gambar 1b. Pohon filogenetik isolat BR883

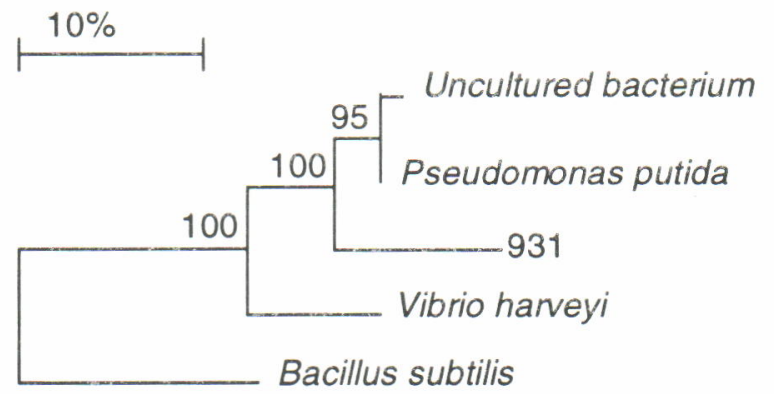

Gambar 1c. Pohon filogenetik isolat BR931 


\section{KESIMPULAN}

Delapan isolat bakteri filosfer yang diisolasi dari daun mangrove potensial sebagai bakteri probiotik pada budi daya udang windu dan bakteri tersebut tidak bersifat patogen terhadap pascalarva udang windu (PL15) pada konsentrasi $10^{4} \mathrm{cfu} / \mathrm{mL}$.

Sintasan larva udang windu tertinggi pada perlakuan yang menggunakan isolat BR931 sebagai probiotik, namun tidak ada perbedaan yang nyata $(P<0,05)$ dengan perlakuan yang lainnya tetapi berbeda nyata $(P<0,05)$ dengan kontrol.

Berdasarkan hasil analisis sekuen gen 16S-rRNA, isolat PK446 teridentifikasi sebagai Kluyvera cryocrescens dengan tingkat kemiripan $79,11 \%$; BR 883 Staphylococcus xylosus dengan tingkat kemiripan 87,22\%; BR 931 termasuk Pseudomonas putida strain $R$ dengan tingkat kemiripan $87,70 \%$.

\section{DAFTAR PUSTAKA}

Ahmad, T. and M. Mangampa. 2000. The use of mangrove stands for bioremediation in a close shrimp culture system. In Hardjito L. (Ed.). Proceedings of International Symposium on Marine Biotechnology. Indonesia, p. 114-122.

Ahmad, T., E. Suryati, and Muliani. 1995. Screening sponge for bactericide to be use in shrimp culture. Ind. Fish. Res. J. 1: 1-10.

Ahmad, T., M. Tjaronge, and F. Cholik. 2001. The use of mangrove stands for shrimp pond waste-water treatment. Ind. Fish. Res. J. 7 (1): 7-15.

Albaladejo, J.D., L.M. Tapay, V.P. Migo, C.G. Alfafara, J.R. Somga, S.L. Mayo, R.C. Miranda, K. Natividal, F.O. Magbanua, T. Itami, M. Matsumura, and E.C.B. Nadala, P. C. 1998. Screening for shrimp viruses in the Philippines. In Flegel TW. (Ed.). Advances in Shrimp Biotechnology. BIOTEC. The National Center for Genetic Engineering and Biotechnology, Thailand, p. 252-253.

Alsina, M. and A.R. Blanch. 1994. A set of keys for biochemical identification of environmental Vibrio species. J. Appl. Bacteriol, 76: 79-85.

Anonimus. 1999. Aquaculture Production Statistics. Food and agriculture organization of The United Nation. Roma, 4 pp.

Atlas, R.M. 1997. Hand Book of Microbiologicak Media. $2^{\text {nd }}$ edition. CRC Press. Boca Raton. New York. London. Tokyo, 1,706 pp.

Atmomarsono, M., Muliani, dan S. Ismawati. 1995. Prospek penggunaan tandon pada budi daya udang windu. Makalah disajikan pada Ekspose Hasil Penelitian di Instalasi Pengkajian Teknologi Pertanian Wonocolo Surabaya, 2-4 Juli 1995, 10 pp.

Austin, B. 1993. Methods in Aquatic Bacteriology. John Wiley and Sons. Chichester. New York. Brisbane. Toronto. Singapore, $425 \mathrm{pp}$.
Austin, B. and D.A. Austin. 1993. Bacterial Fish Pathogens. Disease in farmed and wildfish. $2^{\text {nd }}$ edition. New York. London. Toronto. Sydney. Tokyo. Singapore, $384 \mathrm{pp}$.

Chythanya, R., D.K Nayak, and M.N. Venugopal. 1999. Antibiotic resistance in aquaculture. News from around the world. Infofish International, 6: 30-32.

Chanratchakool, P. and C. Limsuwan. 1998. Application of PCR and Formalin treatment to prevent White Spot Disease in Shrimp. In Flegel TW. (Ed.). Advances in Shrimp Biotechnology. BIOTEC. The National Center for Genetic Engineering and Biotechnology, Thailand, p. $287-289$.

Chanratchakool, P., J.F. Turnbull, S.F. Smith, and C. Limsuwan. 1995. Health Management in Shrimp Ponds. $2^{\text {nd }}$ Edition. Aquatic Animal Health Research Institute. Departement of Fisheries. Kasetsart University Campus. Bangkok, $111 \mathrm{pp}$.

Devaraja, T.N., S.K.Otta, G. Shubha, I. Karunasagar, P. Tauro, and I. Karunasagar. 1998. Immunostimulantion of shrimp through oral administration of Vibrio bacteri and yeast glucan. In Flegel TW. (Ed.) Advances in Shrimp Biotechnology. BIOTEC. The National Center for Genetic Engineering and Biotechnology, Thailand, p. 167-170.

Dhar, A.K., M.M. Roux, and K.R. Klimpel. 2001. Detection and quantification of infectious hypodermal and hematopoietic necrosis virus and White spot Syndrome Virus in shrimp using Real-Time quantitative PCR and SYBR green chemistry. Journal of Clinical Microbiology, 39: 2,835-2,845.

Ferdouse, F. 1999. Japanese and other Asian markets for shrimp-an overview. News from around the world. Infofish International, 6: 23-28.

Gram, L., J. Melchiorsen, B. Spanggaard, I. Huber, and T.F. Nielsen. 1999. Inhibition of Vibrio anguillarum by Pseudomonas fluorescens $\mathrm{AH} 2$, a Possible probiotic treatment of fish. Appl. Environ. Microbiol, 65: $969-973$.

Hadioetomo, R.S. 1993. Mikrobiologi Dasar dalam Praktek: Teknik dan Prosedur Dasar Laboratorium. PT Gramedia, Jakarta, p. 62--68.

Hala, Y. 1999. Penggunaan Gen Penanda Molekular untuk Deteksi Pelekatan dan Kolonisasi Vibrio harveyi pada Larva Udang Windu (Penaeus monodon) [Disertasi]. Program Pascasarjana. IPB. Bogor, $91 \mathrm{pp}$.

Hala, Y. dan A. Suwanto. 2003. Ekspresi Gen inaZ pada Vibrio sp. untuk memantau pelekatan bakteri pada larva udang. Jurnal Mikrobiologi Indonesia, 8: 1318.

Hameed, A.S.S. 1995. Susceptibility of three Penaeus species to a Vibrio campbelli-like bacterium. J. World Aqua. Soc., 26: 315-319.

Haryanti, K. Sugama, S. Tsumura, and T. Nishijima. 2000. Vibriostatic bacterium isolated from seawater: Potentiality as probiotic agent in the rearing of Penaeus monodon larvae. Ind. Fish. Res. J., 6: 2632. 
Itami, T., M. Maeda, N. Suzuki, K. Tokushige, A. Nakagawa, O. Henning, M. Kondo, J. Kasornchandra, I. Hirono, T. Aoki, Kusuda., and Y. Takahashi. 1998. Possible prevention of White Spot Syndrome (WSSV) in kuruma shrimp, Penaeus japonicus, in Japan. In Flegel TW. (Ed.). Advances in Shrimp Biotechnology. BIOTEC. The National Center for Genetic Engineering and Biotechnology, Thailand, p. 291-295.

Itami, T. and Y. Takahashi. 1991. Survival of larval giant tiger prawns Penaeus monodon after addition of killed vibrio cell to a microencapsulated diet. J. Aqua. Anim. Health, 3: 151-152.

Jiravanichpaisal, P., T. Miyazaki, C. Limsuwan. 1994. Histopathology, biochemistry, and pathogenecity of Vibrio harveyi infecting black tiger prawn Penaeus monodon. J. Aqua. Anim. Health, 6: 27-35.

Karunasagar, 1. 2003. Application of Polymerase Chain Reaction for Detection of Shrimp Pathogens in India. Department of Fishery Microbiology, University of Aquacultural Sciences, College of Fisheries, Mangalore-575 002, India, 2 pp.

Karunasagar, I., R. Pai, G.R. Malathi, and I. Karunasagar. 1994. Mass mortality of Penaeus monodon larvae due to antibiotic-resistant Vibrio harveyi invection. Aquaculture; 128: 203-209.

Kono, T., R. Savan, and T. Itami. 2004. Detection of white spot syndrome virus in shrimp by loop-mediated isothermal amplification. J. Virol. Methods, 115: 5965.

Kou, G.H., S.E. Peng, Y.L. Chiu, and C.F. Lo. 1998. Tissue distribution of white spot syndrome virus (WSSV) in shrimp and crabs. In Flegel TW. (Ed.). Advances in shrimp biotechnology. BIOTEC. The National Center for Genetic Engineering and Biotechnology, Thailand, p. 267-271.

Lavilla-Pitogo, C.R., L.L. Baticados, E.R. cruz Lacierda, and L.D. de la Pena. 1990. Occurence of luminous bacterial diseases of Penaeus monodon larvae in the Philippines. Aquaculture, 91: 1-13.

Lavilla-Pitogo, C.R., L.J. Albright, M.G Paner, N.A. Sunaz. 1992. Studies on the source of luminescent Vibrio harveyi in Peneaus monodon hatcheries. In Shariff IN, Subasinghe RP, Arthur R.J. (Eds.), Diseases in Asia Aquaculture. Fish Health Section Asian Fisheries Society, Manila. Philippines, p. 157-164.

Loh, P.C., E. Cesar, J.R.B. Nadala, L.M. Tapay, and Y. Lu. 1998. Recent developments in ImmunologicallyBased and cell culture protocols for the specific detection of shrimp viral pathogen. In Flegel TW. (Ed.). Advances in Shrimp biotechnology. BIOTEC. The National Center for Genetic Engineering and Biotechnology, Thailand, p. 255-259.

Marchesi, J., R.T. Sato, A.J. Weightman, T.A. Martin, J.C. Fry. S.J. Hiom, and W.G. Wade. 1998. Design and evaluation of useful bacterium-spesifik PCR primers that amplify genes coding for bacterial 16S-rRNA. Appl. Environ. Microbiol, 64: 795-799.

Muir, P. 1996. Identification of Vibrio and Pseudomonas bacteria. Departement of Microbiology, Biomedical and Tropical Veterinary Science. James Cook University of North Queensland. Australia, 6 pp.
Muliani, M. Atmomarsono, M.I. Madeali. 1998a. Pengaruh penggunaan kekerangan sebagai biofilter terhadap kelimpahan dan komposisi jenis bakteri pada budidaya udang windu (Penaeus monodon) dengan sistem resirkulasi air. J. Pen. Per. Indonesia, 3: 5461.

Muliani, E. Suryati, dan T. Ahmad. 1996. Peluang pemanfaatan bioaktif sponge sebagai bakterisida. Makalah disampaikan pada Temu IImiah Nasional Bidang Veteriner. Bogor, 9 pp.

Muliani, E. Suryati, dan T. Ahmad. 1998b. Penggunaan ekstrak spons untuk penanggulangan bakteri Vibrio spp. pada udang windu Penaeus monodon. J. Pen. Perik. Ind., 1: 108-115.

Muliani, A. Suwanto, dan Hala. 2003. Isolasi dan karakterisasi bakteri asala laut Sulawesi untuk biokontrol penyakit vibriosis pada larva udang windu (Penaeus monodon Fab.). Hayati, 10: 6-11.

Pasharawipas, T., S. Sriurairatana, S. Direkbusarakom, Y. Donayadol, S. Thaikua, L. Ruangpan, and T.W. Flegel. 1998. Luminous Vibrio harveyi associated with tea brown gill syndrome in black tiger shrimp. In Flegel TW. (Ed.). Advances in Shrimp Biotechnology. BIOTEC. The National Center for Genetic Engineering and Biotechnology, Thailand, p. 213-216.

Peng, S.E., C.F. Lo, S.C. Lin, Chen, Y.S. Chang, K.F. Liu, M.S. Su, and G.H. Kou. 2001. Performance of WSSVinfected and WSSV-negative Penaeus monodon postlarvae in culture ponds. Dis. Aquat. Org., 46: 165-172.

Prescott, L.M., J.P. Harley, and D.A. Klein, 2002. Microbiology. 5th edition. Mc Graw Hill. Boston Burr Ridge, IL Dubuque, IA Madison, WI New York, San Fransisco, Bangkok, Bogota, Caracas, Kualalumpur, Lisbon, London, Madrid, Mexico City, Milan, Montreal, Newdelhi, Santiago, Seoul, Singapore, Sydney, Taipei, Toronto, 1,0026 pp.

Rosa, D., Zafran, I. Tufik, dan M.A. Girsang. 1997 Pengendalian Vibrio harveyi secara biologis pada larva udang windu (Penaeus monodon): I. Isolasi Bakteri Penghambat. J. Penel. Perik. Ind., 3: 1-10.

Ruangpan, L. 1998. Luminous bacteria associated with shrimp mortality. In Flegel, T.W. (Ed.). Advances in Shrimp Biotechnology. BIOTEC. The National Center for Genetic Engineering and Biotechnology, Thailand, p. $205-211$.

Singleton, P. and D. Sainsbury. 1999. Dictionary of Microbiology and Molecular Biology. $2^{\text {nd }}$ edition. A. Wiley-Intersience Publication. John Wiley \&Sons. Chichester. New York. Brisbane. Toronto. Singapore, $1018 \mathrm{pp}$.

Spann, K.M., J.E. Vickers, and R.J.G. Lester. 1995. Lymphoid organ virus of Penaeus monodon from Australia. Dis. Aquat. Org., 23: 127-134.

Steel, R.G.D. and J.H. Torrie. 1981. Principles and Procedures of Statistics. Abiometrical Approach (2 edition). International Student Edition. McGraw-Hill International Book Company, 633 pp.

Sukhumsirichart, W., C. Wongteerasupaya, V. Boonsaeng, S. Panyim, S. Sriurairatana, B. 
Withyachumnarnkul, and T.W. Flegel. 1998. Genome organization and detection of Hepatopancreatic Parvovirus (HPV) from Penaeus monodon in Thailand. In Flegel, T.W. (Ed.). Advances in Shrimp biotechnology. BIOTEC. The National Center for Genetic Engineering and Biotechnology, Thailand, p. $261-262$.

Sung, H.H., G.H. Kou, Y.L. Song. 1994. Vibriosis resistance induced by glucan treatment in tiger shrimp (Penaeus monodon). Fish Pathol., 1: 11-17.

Suryati, E., Rosmiati, W. Moka, and Y. Hala. 2000. Hydrozoan Aglaophenia sp. Bioactive Substance analysis for bactericide. Ind. Fish. Res. J., 6:55-61.

Suwanto, A., Yogiara, D. Suryanto, I. Tan, dan E. Puspitasari. 2000. Selected protocols. Training Course on Advances in Moleculer Biology Techniques to Assess Microbial Diversity. Bogor, 28 pp.

Tjahjadi, M.R., S.L. Angka, and A. Suwanto. 1994. Isolation and evaluation of marine bacteria for biocontrol of luminous bacterial diseases in tiger shrimp larvae (Penaeus monodon Fab.). Aspac. J. Mol. Biol. Biotechnol., 2: 347-352.
Vargas-Albores, F., J. Hernandes-Lopez, T. GollasGalvan, K. Montano-Perez, F. Jimenes-Vega, and G. Yepiz-Plascencia. 1998. Activation of shrimp cellular defence fungtions by microbial products. In Flegel TW. (Ed.). Advances in Shrimp Biotechnology BIOTEC. The National Center for Genetic Engineering and Biotechnology, Thailand, p. 161-166.

Vaseeharan, B., R. Jayakumar, and P.Ramasamy. 2003. PCR-base detection of white spot syndrome virus in cultured and captured crustaceans in India. Lett. Appl Microbiol., 37: 443--447.

Wang, Y.G., O.L. Tan, K.L. Lee, M.D. Hassan, and M. Shariff. 1999. Health management of shrimp during grow-out. News from around the world. Infofish International, 4: 30-35.

Wongteerasupaya, C., S. Sriurairatana, J.E. Vickers, A. Akrajamorn, V. Boonsaeng, S. Panyim, A. Tassanakajon, B. Withyachumnarnkul, and T.W. Flegel. 1995. Yellow-head virus of Penaeus monodon is an RNA virus. Dis. Aquat. Org., 22: 45-50. 
